Editors' Note: Saifee et al. comment on the Pre-Hospital Acute Neurological Treatment and Optimization of Medical care in Stroke (PHANTOM-S) pilot study and discuss the concept of "stroke to syringe time" vs "call to needle time" or "door to needle time." Commenting on the study by Brown et al., "Neighborhood socioeconomic disadvantage and mortality after stroke," Mittal and McCormick suggest potential confounders that may have affected the study results. Sposato and Grimaud dismiss these confounders due to lack of evidence for their effect on stroke mortality.

Chafic Karam, MD, and Robert C. Griggs, MD

\section{PREHOSPITAL THROMBOLYSIS IN ACUTE STROKE: RESULTS OF THE PHANTOM-S PILOT STUDY}

Tabish A. Saifee, Christian M. Burd, Cristina Koppel, London: In their PHANTOM-S pilot study of prehospital administration of thrombolytic treatment for acute ischemic stroke, Weber et al. ${ }^{1}$ explored a method of improving "call to needle times." Despite a widening time window for thrombolysis for acute ischemic stroke, ${ }^{2}$ the importance of minimizing time delay between symptom onset and administration of thrombolytic treatment has led to phrases such as "time is brain" and "door to needle time" to engender this concept. This focus on minimizing hospital factors and delays has been shown to result in better outcomes after thrombolysis in stroke patients. ${ }^{3}$ Weber et al. greatly emphasized this early part of the time window for treatment of stroke. However, equally important delays persist between onset of symptoms and time to patients calling for medical assistance despite public health campaign efforts such as "act FAST" by the UK government and other similar endeavors. ${ }^{4}$ With respect to expediting thrombolytic treatment, we suggest an effort is spread to minimize delays in all parts of this therapeutic window, both prehospital and in-hospital, and so we suggest the recently coined term ${ }^{5}$ "stroke to syringe time" as more reflective of this aim.

(C) 2013 American Academy of Neurology

1. Weber JE, Ebinger M, Rozanski M, et al. Prehospital thrombolysis in acute stroke: results of the PHANTOM-S pilot study. Neurology 2013;80:163-168.

2. Sandercock P, Wardlaw JM, Lindley RI, et al. The benefits and harms of intravenous thrombolysis with recombinant tissue plasminogen activator within $6 \mathrm{~h}$ of acute ischaemic stroke (the third international stroke trial [IST-3]): a randomised controlled trial. Lancet 2012;379:2352-2363.

3. Hacke W, Kaste M, Bluhmki E, et al. Thrombolysis with alteplase 3 to 4.5 hours after acute ischemic stroke. N Engl J Med 2008;359:1317-1329.

4. Kerns JM, Heidmann D, Petty M, Prabhakaran S. Optimizing public health strategies for stroke education: need for a controlled trial. Am J Ther 2011;18:81-90.

5. Hughes T. Chameleons, confusion and the clinical historian. Pract Neurol 2013;13:29-30.

\section{NEIGHBORHOOD SOCIOECONOMIC STATUS AND STROKE MORTALITY: DISENTANGLING INDIVIDUAL AND AREA EFFECTS}

Manoj K. Mittal, Jennifer B. McCormick, Rochester, MN: Brown et al. ${ }^{1}$ reported higher poststroke mortality among residents of the most socioeconomically disadvantaged census tracts relative to the residents of the least disadvantaged census tracts. The authors did not find any association by race or income.

Table e-2 shows that white patients have 1.49 times higher risk of poststroke mortality at 1 year $(p=0.06)$. Interestingly, a previous cardiovascular health study showed 2.9 times higher risk of poststroke mortality in black patients $(p<0.05){ }^{2}$ This association of race and mortality is surprising. The authors could address this paradox by comparing the race/ethnicity of participants who were excluded secondary to geocoding issues with their addresses to those who were included.

Other potential confounders could be patient mobility status and use of IV thrombolysis, which are independent risk factors for poststroke mortality. ${ }^{2-4}$ Black race and low income are significant predictors for not receiving IV thrombolysis. ${ }^{5}$ The effect of neighborhood on mortality should be adjusted for mobility status and use of IV thrombolysis.

Better health policies are needed to improve access of care for minorities and the poor to provide lifesaving, US Food and Drug Administration-approved treatments like IV thrombolysis and poststroke care.

Disclaimer: The views expressed by the authors do not represent the views of the Mayo Clinic.

Author Response: Luciano A. Sposato, London, Canada; Olivier Grimaud, Paris: Drs. Mittal and McCormick comment on the article by Brown et al., ${ }^{1}$ who studied socioeconomic disadvantage and 
mortality after stroke. The authors found a 1.49 times higher risk of poststroke mortality in white patients $(p=0.06)$, which is issued from a multivariate model that included other individual and neighborhood socioeconomic indicators. Mortality after stroke is strongly correlated with socioeconomic status and race. ${ }^{6,7}$ The results of Brown et al. seem to show that, of all other indicators, neighborhood socioeconomic disadvantage displayed the strongest statistical association with poststroke mortality. Thus, it is reasonable that in models including race but no socioeconomic variables, being white may be negatively associated with poststroke mortality. Although IV thrombolysis is a major determinant of ischemic stroke prognosis in terms of disability, evidence shows that it does not affect 1-year mortality. ${ }^{8}$ Whether adjusting for IV thrombolysis (and for other clinical care indicators) would modify the association between neighborhood disadvantage and mortality is therefore unclear. Evidence of gait velocity on stroke mortality is also scarce and needs further confirmation. ${ }^{9}$

C 2013 American Academy of Neurology

1. Brown AF, Liang LJ, Vassar SD, et al. Neighborhood socioeconomic disadvantage and mortality after stroke. Neurology 2013;80:520-527.
2. Longstreth WT Jr, Bernick C, Fitzpatrick A, et al. Frequency and predictors of stroke death in 5,888 participants in the Cardiovascular Health Study. Neurology 2001;56:368-375.

3. Webster F, Saposnik G, Kapral MK, Fang J, O'Callaghan C, Hachinski V. Organized outpatient care: stroke prevention clinic referrals are associated with reduced mortality after transient ischemic attack and ischemic stroke. Stroke 2011;42: 3176-3182.

4. Fischer U, Mono M-L, Zwahlen M, et al. Impact of thrombolysis on stroke outcome at 12 months in a population: the Bern Stroke Project. Stroke 2012;43:1039-1045.

5. Kimball MM, Neal D, Waters MF, Hoh BL. Race and income disparity in ischemic stroke care: nationwide inpatient sample database, 2002 to 2008. J Stroke Cerebrovasc Dis Epub 2012 Jul 17.

6. Kapral MK, Fang J, Chan C, et al. Neighborhood income and stroke care and outcomes. Neurology 2012;79:1200-1207.

7. Howard VJ, Kleindorfer DO, Judd SE, et al. Disparities in stroke incidence contributing to disparities in stroke mortality. Ann Neurol 2011;69:619-627.

8. Kwiatkowski TG, Libman RB, Frankel M, et al. Effects of tissue plasminogen activator for acute ischemic stroke at one year: National Institute of Neurological Disorders and Stroke Recombinant Tissue Plasminogen Activator Stroke Study Group. N Engl J Med 1999;340:1781-1787.

9. Longstreth WT Jr, Bernick C, Fitzpatrick A, et al. Frequency and predictors of stroke death in 5,888 participants in the Cardiovascular Health Study. Neurology 2001;56: 368-375.

\section{CORRECTION}

Anemia and risk of dementia in older adults: Findings from the Health ABC study

In the article "Anemia and risk of dementia in older adults: Findings from the Health ABC study" by C.H. Hong et al. (Neurology ${ }^{\circledR}$ 2013;81:528-533), there is an error in the abstract. The first sentence of "Results" should read as follows: "Of 2,552 participants, 393 (15.4\%) older adults had anemia at baseline." The authors regret the error. 


\section{Neurology}

\section{Neighborhood socioeconomic status and stroke mortality: Disentangling individual and area effects}

Manoj K. Mittal, Luciano A. Sposato, Jennifer B. McCormick, et al. Neurology 2013;81;938-939

DOI 10.1212/01.wnl.0000434339.51805.60

This information is current as of September 2, 2013

Updated Information \& Services

References

Permissions \& Licensing

Reprints including high resolution figures, can be found at: http://n.neurology.org/content/81/10/938.2.full

This article cites 8 articles, 6 of which you can access for free at: http://n.neurology.org/content/81/10/938.2.full\#ref-list-1

Information about reproducing this article in parts (figures,tables) or in its entirety can be found online at:

http://www.neurology.org/about/about_the_journal\#permissions

Information about ordering reprints can be found online: http://n.neurology.org/subscribers/advertise

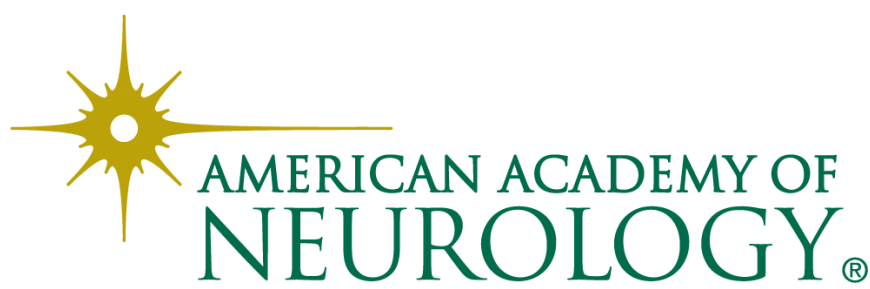

